\title{
Chemical thinning increasing larger fruits and profit in red guava orchards
}

\section{Raleantes químicos aumentam o tamanho de frutos e lucro em pomares de goiaba vermelha}

\author{
Marcelo Souza Silva'; Sarita Leonel2*; Jackson Mirellys Azevedo Souza3; Rafael \\ Bibiano Ferreira4; Rafaelly Calsavara Martins ${ }^{4}$; Rafael Augusto Ferraz ${ }^{5}$
}

\section{Highlights}

Chemical thinners were effectiveness in 'Paluma' guava fruits.

Benzyladenine and ethefhon increased fruit mass depending on the concentrations.

Ethefhon (28.4\%) promoted the best guava commercial classification.

Chemical thinning reduced total operational cost.

Thinners spraying increased net revenue by $7.57 \%$.

\begin{abstract}
The guava is a fruit of strong economic and social relevance, regionally projected and greatly important in some regions of Brazil. The chemical thinning has been adopted in some fruit trees to obtain greater caliber of fruits and better prices. However, some aspects still need to be investigated for the safe and economical viability use of such technique. This research aimed to evaluate the chemical thinning efficiency, production and commercial classification of guava fruits $\mathrm{cv}$. Paluma and provide an economic analysis of this crop system. The ethephon and benzyladenine were applied to fruits with an average size of $18 \mathrm{~mm}$ at $0,150,300$ and $450 \mathrm{mg} \mathrm{L}^{-1}$. The trial was carried out in two crop seasons, and the randomized block design was used as statistical model in a factorial arrangement $2 \times 4$. The economic analysis was calculated through total production operational cost, in order to determine gross revenue, net revenue, profitability index, equilibrium price and yield. The benzyladenine and ethephon promoted the highest percentage of thinning fruits at $450 \mathrm{mg} \mathrm{L}^{-1}$, with averages of $67.6 \%$ and $70.0 \%$, respectively. However, benzyladenine had a phytotoxic effect when applied at highest concentrations, 300 and $450 \mathrm{mg} \mathrm{L}^{-1}$, respectively. The ethephon enabled greater production of larger caliber fruits in the highest concentration (450 $\left.\mathrm{mg} \mathrm{L}^{-1}\right)$. Chemical thinning reduced total operational cost and increased net revenue by $7.57 \%$, as compared to

1 Prof. Dr., Faculdade de Educação Superior e Formação Integral, FAEF, Garça, SP, Brazil. E-mail: mace-lo-souza@ hotmail.com

2 Prof. Dr., Universidade Estadual de São Paulo, UNESP, Botucatu, SP, Brazil. E-mail: sarita.leonel@unesp.br

3 Prof. Dr., Universidade Federal de Viçosa, UFV, Viçosa, MG, Brazil. E-mail: jackson.mirellys@hotmail.com

${ }^{4}$ Doctorate Graduate Students of the Agronomy/Horticulture Graduate Program, UNESP, Botucatu, SP, Brazil. E-mail: aprigio_bibiano@hotmail.com; rcalsavara@yahoo.com.br

5 Prof. Dr., Instituto Federal do Amazonas, IFAM, Itacoatiara, AM, Brazil. E-mail: rafael.ferraz@ifam.edu.br

* Author for correspondence
\end{abstract}

Received: Mar. 02, 2021 - Approved: Mar. 25, 2021 
hand thinning. Results also presented that chemical fruit thinning provided equilibrium yield of $4.98 \mathrm{t} \mathrm{ha}^{-1}$ for 'Paluma' guava fruit, as fresh fruit.

Key words: Psidium guajava L. Plant growth regulators. Ethefhon. Benzyladenine. Economic analysis.

\section{Resumo}

A goiaba é uma fruteira que apresenta grande importância econômica e social, com projeção regional e grande relevância em algumas regiões produtoras no Brasil. O raleio químico tem sido adotado em algumas fruteiras para a obtenção de melhor qualidade e maior calibre dos frutos. Entretanto, alguns aspectos ainda precisam ser avaliados, para o uso seguro desta técnica. Portanto, o objetivo deste estudo foi avaliar a eficiência do raleio químico sobre a produção e a classificação comercial dos frutos de goiaba cv. Paluma e fornecer uma análise econômica deste sitema de cultivo. Foram aplicados ethefhon e benziladenina nas concentrações de a 0,150, 300 e $450 \mathrm{mg} \mathrm{L}^{-1}$ nos frutos com tamanho médio de $18 \mathrm{~mm}$. O experimento foi conduzido em dois ciclos agrícolas em delineamento de blocos casualizados em esquema fatorial 2x4. A análise econômica foi calculada por meio do custo operacional total de produção, receita bruta, receita líquida, índice de lucratividade, preço e produtividade de equilíbrio. A benziladenina e o ethefhon $450 \mathrm{mg} \mathrm{L}^{-1}$ apresentaram a maior porcentagem de raleio químico dos frutos, com médias de 67,6\% e 70,0 $\%$, respectivamente. No entanto, a benziladenina apresentou efeito fitotóxico quando aplicada nas maiores concentrações, 300 e $450 \mathrm{mg} \mathrm{L}^{-1}$, respectivamente. O ethefhon possibilitou maior produção de frutos de maior calibre, na maior concentração $\left(450 \mathrm{mg} \mathrm{L}^{-1}\right)$. O raleio químico reduziu o custo operacional total e aumentou a receita líquida em $7,57 \%$, em relação ao sistema de cultivo com raleio manual, destacando ainda que a adoção do raleio químico de frutos proporcionou rendimento de equilíbrio de 4,98 tha-1 para a goiaba 'Paluma', como fruta de mesa.

Palavras-chave: Psidium guajava, L. Reguladores de crescimento vegetais. Ethefhon. Benziladenina. Análise econômica.

\section{Introduction}

The guava has a great versatility in both food industry and fresh market, as consumer's health habits tends to boost consumption in domestic market, as well as guava export increased, provided that it has been gaining global awareness (Vitti, Lima, \& Martinez, 2020).

Guava is mainly harvested from January to April, the raining season in Brazil, but February is the largest period of harvesting. However, some changes in volume and fruit quality may happen, according to harvest periods (Ramos et al., 2011). The price of guavas varies during harvest periods and according to pulp colour and fruit caliber, since greater fruit caliber and red pulp are often commercialized at higher prices (Dhillon, Boora, Gill, \& Arora, 2018).

Moreover, the production of larger and quoted guavas is guaranteed at better market prices by hand fruit thinning (Khan et al., 2014). The hand thinning ofyoung fruits reduces drains competition, increases growth rate and size of remaining fruits, due to the greater balance in the relation to source/drain (Safaei-Nejad, Shahsavar, \& Mirsoleimani, 2015). Although, hand technique increases production costs, as demands specialized labour. Therefore, 
there is a need to search for less laborious practices, as well as more profitable that can replace hand thinning, thus providing greater sustainability to the agricultural business. Mechanical and chemical thinning appears to be the most promising practices to overcome these drawbacks (Anzanello \& Tadesco, 2017).

'Paluma' is a traditional guava widely grown in Brazil, highly productive, features red-colored pulp, pleasant aroma with medium fruits and much appreciated by consumers (Ribeiro et al., 2020). This is the cultivar with the highest production in the state of São Paulo (Vitti et al., 2020).

The most important substances used to promote the chemical thinning are plant growth regulators (PGRs), such as ethephon ((2-chloroethyl) phosphonic Acid) and benzyladenine (N6-benzyladenine). Ethephon is a PGR of the ethylene chemical group, which in contact with the plant tissue induces the release of this hormone. The increase of the ethylene concentration in plant tissues increases the sensitivity of the abscission layer to ethylene, which triggers the organ to fall due to the synthesis of enzymes that hydrolyze the cell wall, such as cellulase and polygalacturonase (lqbal et al., 2017).

Benzyladenine is a PGR of the chemical group of cytokinins that reduces the transport of auxin throughout the fruit peduncle and increases sensitivity of the abscission zone to ethylene, leading to its fall. Since cytokinins share the same ethylene signal amplification pathway, the use of benzyladenine may also increase the concentration of ethylene in plant tissues, aiding in the process of fruit abscission (Zwack, Robinson, Risley, \& Rashote, 2013).

Although the efficacy of ethephon and benzyladenine in the chemical thinning in some fruits, as peach (Giovanaz, Bartz, Pasa, Chaves, \& Fachinello, 2016) and mandarin (Safaei-Nejad et al., 2015) and in guava, with naphthalene acetic acid (Abbas, Ahmad, \& Javaid, 2014) was evaluated and already proven, there is a requirement in literature on the use of these substances for guava.

The chemical thinning performance is dependent on the effectiveness of the substance used and on variables such as the application time, product concentration, spray volume, environmental conditions at the moment and after application, mainly temperature and relative humidity, and characteristics of each species and cultivar. Thus, aspects and adjustments need to be investigated for the safe dose recommendation of a PGR in the chemical thinning of fruits in 'Paluma' guava, considering that will contribute to the better management, aiming the production of fruits for natural consuption.

The current research aimed to evaluate the chemical thinning effectiveness, commercial classification of the fruits and production per tree and assessing the economic viability through production cost for producing 'Paluma' guava submitted to chemical fruit thinning.

\section{Material and Methods}

\section{Experimental area characterization}

The trial was carried out in two crop seasons (2015/2016 and 2016/2017) at São Manuel Experimental Farm of the São Paulo State University (UNESP), Brazil (22 44'28" $\mathrm{S}$ and 48 $34^{\prime} 37^{\prime \prime} \mathrm{W}$ and $740 \mathrm{~m}$ asl). The region has a Cfa climate (humid subtropical 
climate, mesothermic), according to the Köppen classification system. The soil was classified as a sandy-textured dystroferric Red Latosol (Empresa Brasileira de Pesquisa Agropecuária [EMBRAPA], 2006). Before the experiment implementation, soil samples (0 to $20 \mathrm{~cm}$ depth) were collected and the chemical characteristics were determined. Based on soil analysis and guava crop recommendations, experimental area was previously prepared with plowing, sorting and liming.

The orchard with 6-year-old 'Paluma' guava trees (Psidium guajava) were spaced $6 \mathrm{~m}$ between rows and $4 \mathrm{~m}$ between trees (i.e., 416 trees $\mathrm{ha}^{-1}$ ), and without irrigation. Crop management was based on the recommendations for the crop.

A weather station, located within $100 \mathrm{~m}$ of the experimental area, recorded air temperature, humidity, precipitation, wind speed and solar radiation. Data were archived by the College of Agricultural Sciences, Department of Agricultural Engineering, São Paulo State University (UNESP) and are available to the public (www.fca.unesp.br).

\section{Thinners spraying and harvest}

The ethephon ([2-Chloroethyl phosphonic acid] 24\%) (Ethephon ${ }^{\circledR}$ ) and benzyladenine ([6-benzyladenine] 2\%) (Maxcell ${ }^{\circledR}$ ) were applied at 0, 150, 300 and $450 \mathrm{mg} \mathrm{L}^{-1}$, using four replicates and tree trees per experimental plot. The randomized block design in a factorial arrangement $2 \times 4$ was used as statistical model, being the first factor the PGRs and the second factor the concentrations.

Thethinnerswereappliedwhen'Paluma' guava fruits achieved an average size of 18 $\mathrm{mm}$. Each tree received $2.5 \mathrm{~L}$ of spray volume, wich contained different concentrations of PGRs and $3 \%$ of surfactant $\left(\right.$ Agral $^{\circledR}$ ). Within both crop cycles, the evaluations started at 84 days after pruning production, made in beginning of September in the two crop seasons (Silva, Tecchio, Domiciano, Leonel, \& Balestero, 2016).

The fruits were harvested when they began to show a yellowish-greenish peel color, which corresponds to stage 4 of maturation, as recommended by Cavalini, Jacomino, Trevisan and Miguel (2015).

Fruits thinned percentage, fruit mass and production

Prior to the application of the treatments, 10 productive and well distributed branches were identified and marked in the crown of each guava tree, counting the initial number of fruits in each of these branches. Such operation was repeated 35 days after PGRs spraying, when there was stabilization of thinned fruits number. The percentage of thinned fruits was calculated by means of Equation 1.

$\%$ thinned fruits $=[(n 0-n 35) \div n 0] \times 100$

Where "n0" refers to the initial number of fruits and "n35" corresponds to the number of fruits 35 days after application of the treatments.

The fruit number per marked branch and fruit fresh mass (g) was determined by counting the total number of fruits in 10 branches marked on each tree at the end of the harvest period. The production per tree ( $\mathrm{kg} /$ tree) was calculated by the sum of the weight of all fruits harvested on the trees. 


\section{Guavas commercial classification}

Guavas commercial classification was evaluated according to Hortiescolha Companhia de Entrepostos e Armazéns Gerais de São Paulo [CEAGESP] (2020), a support program for deciding on the choice of fresh fruits and vegetables, based on the equatorial diameter of the guavas harvested (Figure 1).
For this evaluation, 25 fruits were randomly chosen in each experimental plot, totaling 100 fruits per treatment and measurements were made with the aid of a digital caliper, with results expressed in $\mathrm{mm}$. After the measurements, the percentage of fruit within each gauge was determined, based on its respective diameter.

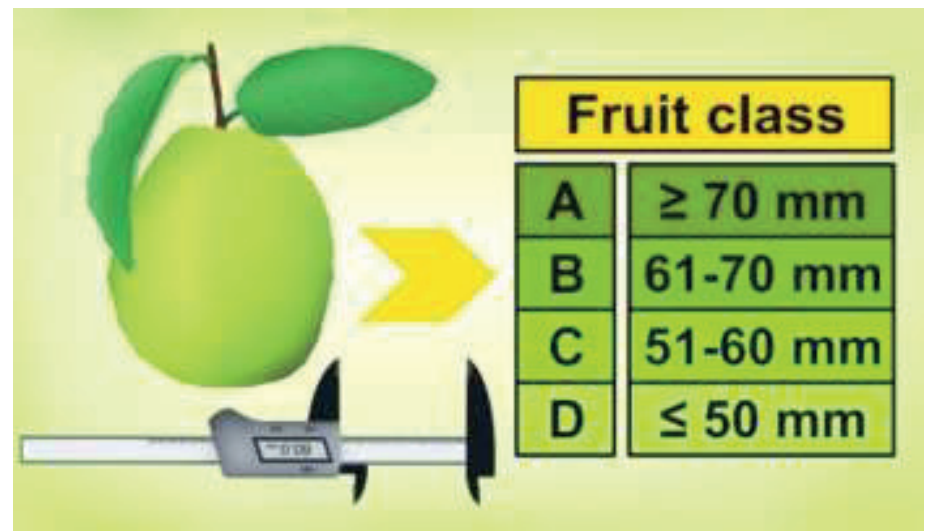

\section{Economic analysis}

The data for hand thinning were based on OuroFrut producer's report (Association of Integrated Production of Goias) for Carlópolis region, state of Paraná, Brazil. With regards to chemical thinning, data was obtained in two cycles (2015-2016 and 2016-2017) and readjusted in November 2020. Therefore, consumed inputs (machinery and labor time) were computed for each operation, defining technical coefficients in terms of machine/ man hours and materials per unit area.

Since orchard was already in full productive activity at the beginning of this study, the implantation cost of the crop was not calculated, besides that both thinning techniques (hand or chemical) did not affect such cost. According to Institute of Agricultural Economics (IEA), production cost is calculated through the structure of total production operational cost. Operational costeffectiveness (OCE) comprises expenses with materials consumed, mechanized and hand operations. If costs of interest, other expenses and depreciation are added to OCE, then total operating costs (TOC) are calculated (Matsunaga et al., 1976).

The manual expenses were calculated considering the labour man-day BRL. 60.00 in São Manuel region, state of São Paulo, while average machine hour (MH) was BRL. 110.00 . Also, the cost interest of $8.50 \%$ per year was considered on operational cost-effectiveness; and $5 \%$ on the OCE for other expenses. 
The harvesting costs were estimated by the cost per kg of fruit and the profitability index in production system with hand harvesting. Data were obtained on 'Paluma' guava production from OuroFrut farm. For chemical thinning costs, the plant growth regulator ethephon was considered at 450 $\mathrm{mg} \mathrm{L}^{-1}$ i.a. and spray volume of $2.5 \mathrm{~L} /$ tree. Data were collected for input price from the website of IEA (Institute of Agricultural Economics), as well as agricultural suppliers in São Manuel region.

The average prices were BRL.3.73 $\mathrm{kg}^{-1}$ of fresh fruit according to Ceagesp, from February to April (2016, 2017 and 2020 harvest seasons), in addition, $30 \%$ was discounted of total amount paid for commercialization.

Production cost was calculated through the structure of the total production operational cost, according to Institute of Agricultural Economics (IEA). Treatments profitability was calculated multiplying the price of the kilo of the fruit by the average productivity $\left(\mathrm{kg} \mathrm{ha}^{-1}-\mathrm{GR}=\right.$ Price $\mathrm{x}$ productivity). Furthermore, net revenue (NR) was calculated, referring to difference between gross revenue and total operational cost, (NR = GR-TOC) (Matsunaga et al., 1976).

In addition to the indexes described, profitability index (PI) was defined as the proportion of gross revenue that constituted available resources after covering total operational production cost, i.e. $\mathrm{PI}=$ (NT/ GR) $x$ 100. Equilibrium price $(E p)$ was the total production operational cost, as minimum price, required to cover TOC, taking into account average yield obtained by producer, i.e., Ep = TOC/average yield obtained by producer. The equilibrium yield (Ey) was total production operating cost, as minimum yield was required to cover TOC, considering the average price received by producer, i.e., Ey $=$ TOC/average price received by producer.

\section{Statistical analysis}

Two years of data for evaluated variables were analyzed as repeated measures. The Shapiro-Wilk test was applied to test normality. The data were submitted to analysis of variance. When significant, the data related to the factor "thinners" (Benzyladenine and Ethephon) were submitted to the Tukey test while the data referring to the factor "concentrations of plant growth regulators" was analysed by means of regression $(p<0,01$ and $p<0.05)$. The data for fruit thinned percentage were transformed to arcsen $\sqrt{ } \mathrm{x} / 100$.

For all the analyses was used the Computer Program System for Analysis of Variance - SISVAR. All graphics presented were made using the SigmaPlot Computational Program for Windows (Systat Inc. Chicago, IL, USA) version 12.5 .

\section{Results and Discussion}

\section{Thinned fruits percentage}

There was significant interaction $(p<0.05)$ between the PGRs and the concentrations used for percentage of thinned fruits (Table 1). There was a linear increase in the percentage of thinned fruits when using PGRs (Figure 2). The highest concentrations $(450 \mathrm{mg}$ $\mathrm{L}^{-1}$ ) resulted in averages of $67.6 \%$ and $70.0 \%$ for benzyladenine and ethephon, respectively. Both PRGs differed in the concentration of 300 $m g L^{-1}$, been ethephon more effect on fruit thinning than benzyladenine. 
Table 1

F-values, degrees of freedom (DF), coefficients of variation (CV) and means of evaluated variables of 'Paluma' guava fruits after chemical thinning

\begin{tabular}{|c|c|c|c|c|c|}
\hline & \multicolumn{5}{|c|}{ F-values } \\
\hline & DF & TFP & NFB & FM & PRO \\
\hline Block & 3 & $0.12 \mathrm{~ns}$ & $1.09 \mathrm{~ns}$ & $0.35 n s$ & $1.23 \mathrm{~ns}$ \\
\hline PGRs (A) & 1 & $0.59 \mathrm{~ns}$ & $0.62 n s$ & $0.88 n s$ & $1.59 \mathrm{~ns}$ \\
\hline Concent (B) & 3 & $20.93^{* *}$ & $20.55^{\star *}$ & $12.40^{* *}$ & $2.03 \mathrm{~ns}$ \\
\hline$A \times B$ & 3 & $3.14^{*}$ & $0.62 n s$ & $0.09 n s$ & $3.19 *$ \\
\hline CV & & 9.97 & 17.41 & 6.60 & 24.28 \\
\hline Mean & & 56.17 & 7.42 & 190.10 & 56.03 \\
\hline \multicolumn{6}{|c|}{ Fruits Diameter } \\
\hline & DF & Class A & Class B & Class C & Class D \\
\hline & & $\geq 70 \mathrm{~mm}$ & $61-70 \mathrm{~mm}$ & $51-60 \mathrm{~mm}$ & $\leq 50 \mathrm{~mm}$ \\
\hline Block & 3 & $5.32^{* *}$ & $0.72 n s$ & $2.78 \mathrm{~ns}$ & $2.51 \mathrm{~ns}$ \\
\hline PGRs (A) & 1 & $3.28^{*}$ & $1.40 \mathrm{~ns}$ & $0.19 n s$ & $1.11 \mathrm{~ns}$ \\
\hline Concent. (B) & 3 & $0.49 n s$ & $0.02 n s$ & $0.06 n s$ & $1.48 \mathrm{~ns}$ \\
\hline$A \times B$ & 3 & $1.37 \mathrm{~ns}$ & $1.08 \mathrm{~ns}$ & $0.59 \mathrm{~ns}$ & $1.31 \mathrm{~ns}$ \\
\hline $\mathrm{CV}$ & & 11.57 & 9.55 & 13.33 & 46.49 \\
\hline Mean & & 26.34 & 45.97 & 25.90 & 1.78 \\
\hline
\end{tabular}

TFP $=$ thinned fruits percentage; $\mathrm{NFB}=$ number of fruits per branch; $\mathrm{FM}=$ fruit mass and $\mathrm{PRO}=$ production per plant ns $=$ not significant; ${ }^{*}$ significant at $5 \%$ and ${ }^{* *}$ significant at $1 \%$ by test $\mathrm{F}$.

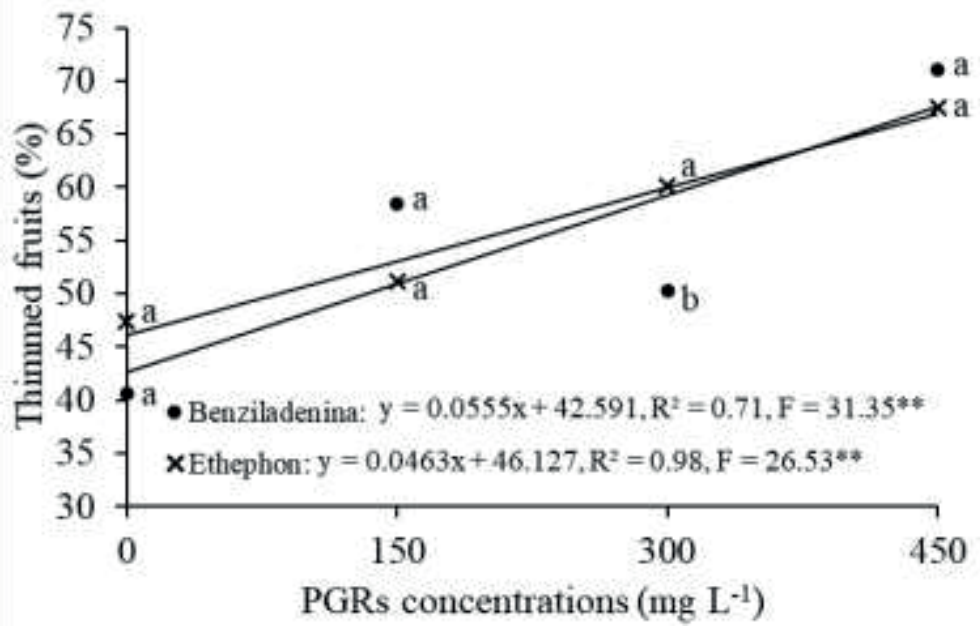

Figure 2. Percentage of thinned fruits (\%) of 'Paluma' guava trees subjected to the application of chemical thinners. Means followed by the same letters do not differ by the Tukey's test $(p<0.05)$. 
Evaluating the influence of the chemical thinning of 'Gola' guava flowers with the application of naphthalenoacetic acid (NAA), Abbas et al. (2014) verified that two applications of this PGR at $400 \mathrm{mg} \mathrm{L}^{-1}$ promoted the flowers thinning in $64.9 \%$. According to the same authors, in the region the Faisalabad, Pakistan, the practice of chemical thinning during flowering of the trees is aimed at avoiding production in the summer, a time of increased incidence of pests and diseases.

The increase in percentage of thinning observed in the highest concentrations of ethephon was possibly associated to the fact that exogenously applied ethephon stimulates ethylene production and triggers ethylene-dependent reactions, such as the abscission of flowers or fruits (Torres, GinéBordonaba, \& Asín, 2021). The role of ethylene in the thinning action of other chemicals remains controversial (Dennis, 2000). The risk of over thinning is much higher with this product (Mahmood, Mohammad, Ali, Ripa, \& Hossain, 2016). Nevertheless, in this study no defoliation and over thinning were observed in all the ethephon concentrations.

The thinning effect of benzyladenine is explained by the this group of thinners enhance cell division leading to larger fruit at harvest and are considered to be mild thinners, can be used jointly with other products to obtain desired thinning effect (Mahmood et al., 2016). It is important to highlight that the use of benzyladenine in the highest concentrations (300 and $450 \mathrm{mg} \mathrm{L}^{-1}$ ) caused phytotoxicity, such as tanning symptoms at the ends of leaves and fruits (Figure 3). This is a problem for the commercialization of fruits produced for natural consumption, as it makes them less attractive and depreciates their price. Kretzschmar, Marodin, Duarte, ValdebenitoSanhueza and Guerra (2007) also observed these symptoms in apples trees, indicating the need for adjustments in benzyladenine concentrations, maybe decreasing the concentrations intervals. Note that the smaller the concentration to be applied the lower the costs with the thinner acquisition, representing a saving for the guava grower.

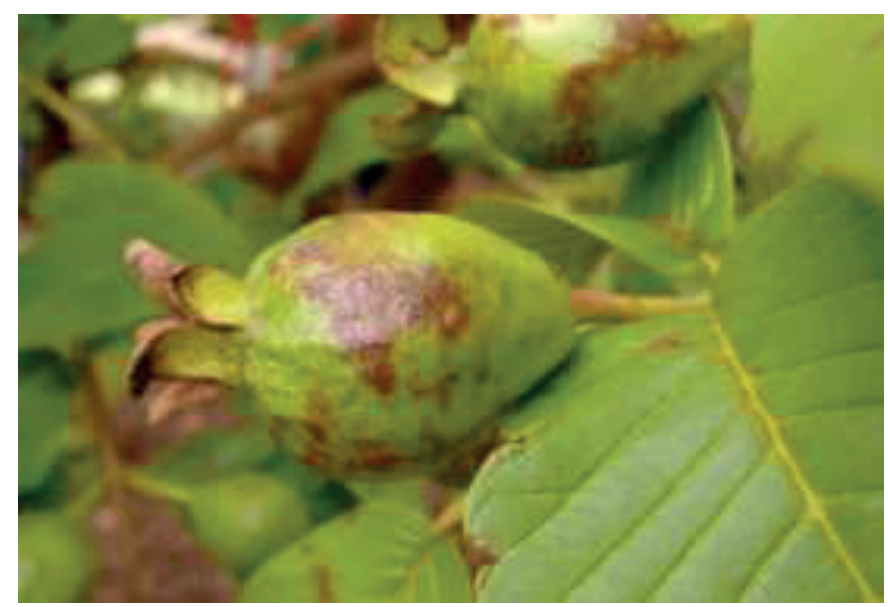

Figure 3. Taning symptoms observed in guavas sprayed with benzyladenine 300 and $450 \mathrm{mg} \mathrm{L}^{-1}$. 


\section{Fruits diameter}

When the fruits were classified by their diameters, it was observed that only those of class $A$ ( $\geq 70 \mathrm{~mm}$ ) were affected by the PGRs spraying $(p<0.05)$. The other classes were not affected by the PGRs or concentrations (Table 2). The application of ethephon promoted the production of $28.4 \%$ of class A fruits, while the application of benzyladenine resulted in
$24.3 \%$ of fruits in this class. This is a good result, as larger fruits are sold at higher prices. The ethephon $300 \mathrm{mg} \mathrm{L}^{-1}$ resulted in a higher percentage of fruit thinning in relation to benzyladenine. This may have affected the source/drain relation in this treatment and allowed the greater percentage of fruits within the valuation class $A(\geq 70 \mathrm{~mm}$ ) obtained with this PGR.

\section{Table 2}

Percentage of 'Paluma' guava fruits treated with chemical thinner in each class of commercialization

\begin{tabular}{ccccc} 
Treatments & \multicolumn{4}{c}{ Fruits by class $(\%)$} \\
Benzyladenine & $24.31 \mathrm{~b}$ & $46.94 \mathrm{a}$ & $26.44 \mathrm{a}$ & $2.34 \mathrm{a}$ \\
Ethephon & $28.00 \mathrm{a}$ & $44.69 \mathrm{a}$ & $24.53 \mathrm{a}$ & $2.47 \mathrm{a}$ \\
Mean & 26.17 & 45.81 & 25.48 & 2.41 \\
CV (\%) & 11.57 & 9.55 & 13.33 & 16.49
\end{tabular}

Means followed by the same letter in the column did not differ statistically from each other by Tukey's test $(p<0.05)$.

These results are important for the guava growers, due to the better price paid for the larger caliber fruits. In CEAGESP, the marketing of red guavas occurs in cartons with an average weight of $2 \mathrm{~kg}$, containing 9, 12, 15 or 18 fruits per box, respectively, depending on their caliber. Thus, the caliber of guavas is one of the quality attributes used to determine the price in the fresh fruit market, that is, the larger the size of the fruit produced, the better the remuneration for the same. Prices might vary according to pulp colour and fruit caliber, since greater fruit caliber and red pulp are often commercialized at higher prices.
Number of fruits per branch, fruit mass and production per tree

The number of fruits per branch $(p<0.01)$ and the fruit fresh mass $(p<0.01)$ were affected only by the concentrations (Table 1). The isolated effect of PGRs concentrations on the number of fruits per branch presented a linear decrease as a function of concentrations increase (Figure 4A), while the fruit fresh mass increased linearly with the elevation of the concentrations of the thinners (Figure 4B). These results corroborated with Dhillon et al. (2018) who verified that the fruit weight increased with increasing concentrations of NAA and ethrel and the maximum number of fruits per tree were recorded in NAA $400 \mathrm{mg} \mathrm{l}^{-1}$ but decreased with increasing concentrations in guava cv. Shweta. 

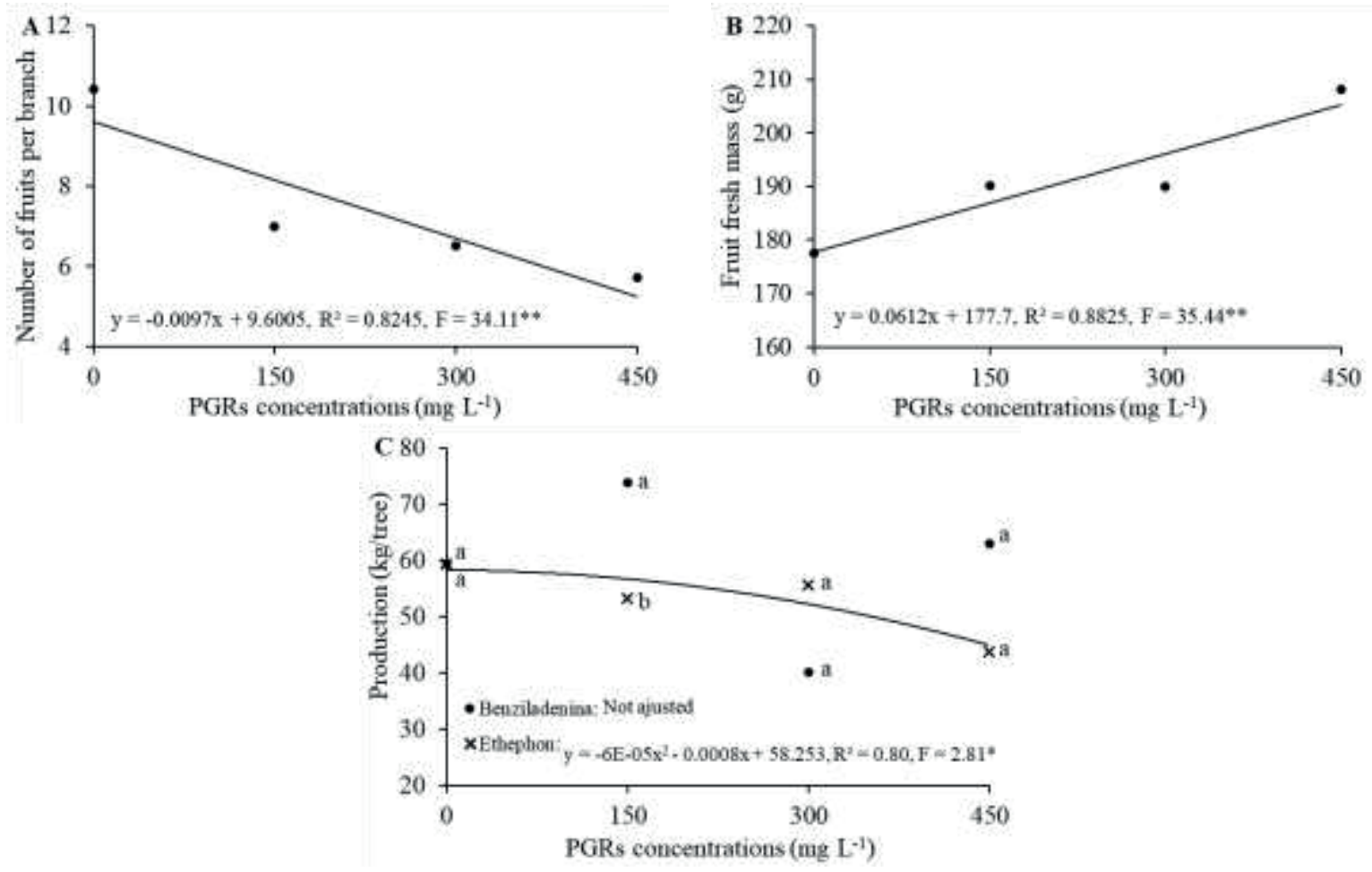

Figure 4. Number of fruits per branch (A) fruit fresh mass $(B)$ and production per tree (C) of 'Paluma' guava as a function of the concentrations of PGRs in fruits chemical thinning.

The increase in fruit mass at the expense of the smaller number of fruits per branch is closely related to the lesser competition between drains, increasing the growth rate and the final size of the remaining fruits, due to the greater balance in the drain source ratio of the plants (Abbas et al., 2014; Giovanaz et al., 2016).

There was a significant interaction between PGRs and concentrations for the production per tree (Table 1). The application of ethephon provided a quadratic adjustment of the production values and the averages did not adjust to regression models when using benzyladenine, allowing suggesting the need for further studies evaluating lower concentrations for 'Paluma' guava (Figure
4C). Dhillon et al. (2018) also reported that the guava fruit yield decreased with increasing concentrations of NAA and ethephon.

The concentration of $450 \mathrm{mg} \mathrm{L}-1$ (ethephon) promoted a production $22.93 \%$ less than obtained without application. However, with this same concentration there was an increase of $17.25 \%$ in the fruit mass. Since larger fruits are destined for more demanding markets, they are consequently sold at high prices, which justify the application of this type of technique. However, its application should be avoided when there is no significant gain in fruit size.

Chemical thinning is beneficial for fruit growth because the relationship between the source of the collector and the collector size 
is regulated during the cell division period of fruit growth (Schröder, 2013). However, the use of these PGRs can positively or negatively influence some aspects of fruit growth (Link, 2000). Thus, this study may provide significant insights into chemical thinning in guava crop.

\section{Economic analysis}

The cost for producing one hectare of 'Paluma' guava with hand fruit thinning was $58.74 \%$ of total operational cost, being harvesting $(20.30 \%)$ and hand fruit thinning $(16.78 \%)$ the highest expenses in total operating costs (Table 3). Tokairin, Cappello and Spósito (2014) evaluating the cost of producing guavas for fresh consumption, with and without bagging, observed that $17.17 \%$ of total operational cost was allocated to hand work. However, did not consider expenses related to hand pruning and harvesting to calculate production costs, justifying the lower expenditure on hand operations. Regarding the amount spent on hand operations chemical fruit thinning provided a reduction of $8.66 \%$ in production costs.

Pavanello and Ayub (2012); Ahrens, Pavanello, Ahren, Francisco and Ayub (2014) compared the both systems in plums orchards and concluded that yields were similar, but production cost has dropped down by using chemical fruit thinning representing an advantage for growers, provided that it promotes price competitiveness. Chemical thinning showed another advantage, since it is less dependent on labour, especially considering the high cost and difficulty of hiring high quality service.

Despite the use of chemical fruit thinning, hand operations were still responsible for the highest expenses (50.08\%) for producing fresh 'Paluma' guava fruits. Regarding to chemical thinning's production costs, total operational cost was BRL. $18,569.36$, which resulted in savings of BRL. $3,569.90$ compared with hand fruit thinning. According to Meland and Birken (2010) this saving can increases profit margin for fresh fruit growers, as well as improving market value.

The average price paid per $\mathrm{kg}$ of fruit (BRL. 3.73), production (BRL. 18,200 kg ha-1) and gross revenue (BRL. 45,520.20) were considered in both production systems. Other indexes were estimated for each thinning system, according to their total operational costs (Table 4). Furthermore, gross revenue already included $30 \%$ discount related to the commercialization in both thinning systems. The lowest total operating cost (TOC) observed for chemical thinning (BRL.18,569.4 ha-1), as compared to hand thinning (BRL.22,166.3 $\mathrm{ha}^{-1}$ ) is due to the lower need for manpower to carry out it. As a consequence of the lower TOC, there was still a higher profitability index in relation to hand thinning. 


\section{Table 3}

Description of operations, materials and total value for producing 'Paluma' guava with hand and chemical fruit thinning, estimated at 1 ha (466 plants per ha-1). São Manuel-SP

\begin{tabular}{|c|c|c|c|c|}
\hline \multirow{3}{*}{ Costs } & \multicolumn{4}{|c|}{ Production systems } \\
\hline & \multicolumn{2}{|c|}{ Hand thinning } & \multicolumn{2}{|c|}{ Chemical thinning } \\
\hline & BRL. ha-1 & $\%$ TOC & BRL. ha ${ }^{-1}$ & $\% \mathrm{TOC}$ \\
\hline Mechanized Operations & 1.210 .00 & 5.46 & 1.210 .00 & 6.52 \\
\hline Rotating (3x) & 330.00 & 1.49 & 330.00 & 1.78 \\
\hline Spraying of micronutrients & 110.00 & 0.50 & 110.00 & 0.59 \\
\hline Spraying of agricultural pesticides (7x) & 770.00 & 3.47 & 770.00 & 4.15 \\
\hline Hand Operations & 13.020 .00 & 58.74 & 9.300 .00 & 50.08 \\
\hline Soil fertilization $(3 x)$ & 720.00 & 3.25 & 720.00 & 3.88 \\
\hline Pruning for cleaning and production & 2.280 .00 & 10.29 & 2.280 .00 & 12.28 \\
\hline Hand thinning & 3.720 .00 & 16.78 & 0.00 & 0.00 \\
\hline Fruit bagging (6x) & 1.800 .00 & 8.12 & 1.800 .00 & 9.69 \\
\hline Harvesting $(15 x)$ & 4.500 .00 & 20.30 & 4.500 .00 & 24,23 \\
\hline Materials & 5.299 .75 & 23.91 & 5.299 .75 & 28.54 \\
\hline Bags for fruit packing & 291.20 & 1.31 & 291.20 & 1.57 \\
\hline Limestone & 89.15 & 0.40 & 89.15 & 0.48 \\
\hline NPK Fertilizer 20:05:20 & 1.906 .86 & 8.60 & 1.906 .86 & 10.27 \\
\hline Single super phosphate & 490.33 & 2.21 & 490.33 & 2.64 \\
\hline Organic compost & 432.64 & 1.95 & 432.64 & 2.33 \\
\hline Zinc sulfate & 0.60 & 0.003 & 0.60 & 0.003 \\
\hline Boric acid & 5.00 & 0.02 & 5.00 & 0.03 \\
\hline Folicur & 166.61 & 0.75 & 166.61 & 0.90 \\
\hline Recop & 72.93 & 0.33 & 72.93 & 0.39 \\
\hline Amistar Top & 1.199 .68 & 5.41 & 1.199 .68 & 6.46 \\
\hline Provado & 644.75 & 2.91 & 644.75 & 3.47 \\
\hline Chemical thinning & 0.00 & 0.00 & 550.92 & 2.97 \\
\hline Spraying with vegetable regulator & 0.00 & 0.00 & 150.00 & 0.81 \\
\hline Ethephon & 0.00 & 0.00 & 400.92 & 2.16 \\
\hline Operation cost-effectiveness (OCE) & 19.529 .75 & 88.11 & 16.360 .67 & 88.11 \\
\hline Other expenses (5\%) & 976.49 & 4.41 & 818.03 & 4.41 \\
\hline Interest rate (8.5\% pa) & 1.660 .03 & 7.49 & 1.390 .66 & 7.49 \\
\hline Total operational cost (TOC) & 22.166 .26 & & 18.569 .36 & \\
\hline
\end{tabular}




\section{Table 4}

Mean fruit price (FP) at CEAGESP, production (PRO), total operating cost (TOC), gross income (GI), net revenue (NR), profitability index ( $\mathrm{PI})$, equilibrium price $(\mathrm{Ep})$ and and equilibrium yield (Ey) for 'Paluma' guava trees subjected to hand and chemical fruit thinning. São Manuel. SP

\begin{tabular}{ccccccccc} 
Thinning & $\begin{array}{c}\mathrm{FP} \mathrm{kg}^{-1} \\
(\mathrm{BRL})\end{array}$ & $\begin{array}{c}\mathrm{PRO} \\
\left(\mathrm{kg} \mathrm{ha}^{-1}\right)\end{array}$ & $\begin{array}{c}\mathrm{TOC} \\
(\mathrm{BRL})\end{array}$ & $\begin{array}{c}\mathrm{GI} \\
(\mathrm{BRL})\end{array}$ & $\begin{array}{c}\mathrm{NR} \\
(\mathrm{BRL})\end{array}$ & $\begin{array}{c}\mathrm{PI} \\
(\%)\end{array}$ & $\begin{array}{c}\mathrm{Ep} \\
(\mathrm{BRL})\end{array}$ & $\begin{array}{c}\text { Ey } \\
\left(\mathrm{t} \mathrm{ha}^{-1}\right)\end{array}$ \\
\hline Hand & 3.73 & 18.200 & 47.520 .2 & 22.166 .3 & 25.353 .9 & 53.35 & 1.22 & 5.94 \\
Chemical & 3.73 & 18.200 & 47.520 .2 & 18.569 .4 & 28.950 .8 & 60.92 & 1.02 & 4.98
\end{tabular}

The results for net revenue (NR) with hand thinning was BRL.25, 353.90 ha $^{-1}$ while with chemical thinning was BRL. 28,950.80 ha1. Consequently, an increase in net revenue by approximately $7.57 \%$. The difference between TOC and OP in hand thinning was BRL. 3,187.60 and the same difference increased to BRL. $10,381.40$ for chemical thinning.

The profitability index (PI), which is the proportion of gross revenue that is constituted of available resources after covering the total production costs, it was observed that this index was $53.35 \%$ for hand thinning and $60.92 \%$ for chemical thinning. As the equilibrium price is directly related to TOC, the adoption of cultivation techniques that reduce TOC indirectly favours Ep, as it can be noticed a lower equilibrium price for chemical thinning (BRL. 1.02) in relation to hand fruit thinning (BRL. 1.22), since hand thinning increases TOC. The chemical thinning of guava fruits decreased equilibrium price in 0.20 cents, corroborating with the results obtained by Pavanello and Ayub (2012), in which the adoption of this technique made fruit price more competitive.

The equilibrium yield comparison in both thinning types, were found Ey values of 5.94 for hand and $4.98 \mathrm{t} \mathrm{ha}^{-1}$ for chemical thinning, respectively. These results indicate that in hand fruit thinning system would be necessary to produce $0.96 \mathrm{t}$ more guavas to cover TOC, considering the average price received by grower in relation to chemical fruit thinning.

\section{Conclusions}

Plant growth regulators improved fixation of larger fruits depending on concentration. The use of ethephon promoted a higher percentage of larger caliber fruits and the spraying of benzyladenine in the highest concentrations caused symptoms of phytotoxity in the fruits.

Chemical fruit thinning can be used to reduce total operating cost due net revenue was $7.57 \%$ higher than hand thinning. The adoption of this technique results in balanced profitability, which allows and greater economic return for the guava growers.

\section{Acknowledgements}

This research was supported by the Brazilian National Council for Scientific and Technological Development (CNPq. Process 304455/2017-2). 


\section{References}

Abbas, M. M., Ahmad, S., \& Javaid, M. A. (2014). Effect of naphthalene acetic acid on flower and fruit thinning of summer crop of guava. Journal of Agricultural Research, 52(1), 111-116. Retrieved from https://apply.jar. punjab.gov.pk/upload/1396007891_112 Microsoft_Word_-_11._4224.pdf

Ahrens, R. de B., Pavanello, A. P., Ahren, D. C., Francisco, A. C. de, \& Ayub, R. A. (2014). Análisis económico del raleo químico y hand en ciruela. Revista de Ciencia y Tecnología de América, 39(10), 723-726. Retrieved from https://www.redalyc.org/ pdf/339/33932433007.pdf

Anzanello, R., \& Tedesco, A. (2017). Chemical thinning of flowers and fruits of the peach cultivar Coral with hydrogen cyanamide. Ciência Rural, 47(10), ed.20151498. doi: 10.1590/0103-8478cr20151498

Cavalini, F. C., Jacomino, A. P., Trevisan, M. J., \& Miguel, A. C. A. (2015). Harvest time and quality of Kumagai and Paluma guavas. Revista Brasileira de Fruticultura, 37(1), 64-72. doi: 10.1590/0100-2945-013/14

Companhia de Entrepostos e Armazéns Gerais de São Paulo (2020). Hortiescolha - Goiaba. Retreived from http://www. ceagesp.gov.br/entrepostos/servicos/ hortiescolha/goiaba/

Dennis, F. G., Jr. (2000). The history of fruit thinning. Plant Growh Regulating, 31(1), 1-16. doi: 10.1023/A:1006330009160

Dhillon, J. S., Boora, R. S., Gill, D. S., \& Arora, N. K. (2018). Effect of different chemicals and hand thinning on crop regulation in guava (Psidium guajava L.) cv. Shweta. Agricultural Research Journal, 55(2),
365-369. doi: 10.5958/2395-146X.2018. 00067.4

Empresa Brasileira de Pesquisa Agropecuária (2006). Sistema brasileiro de classificação de solos (2a ed.). Rio de Janeiro: Embrapa. Recuperado de https://www.embrapa.br/ en/busca-de-publicacoes/-/publicacao /1094003/sistema-brasileiro-de-classifi cacao-de-solos

Giovanaz, M. A., Bartz, J., Pasa, M. S., Chaves, F. C., \& Fachinello, J. C. (2016). Chemical thinning affects yield and return flowering in 'Jubileu' peach. Revista Ceres, 63(3), 329-333. doi: 10.1590/0034-737X20166 3030008

Iqbal, N., Khan, W. A., Ferrante, A., Trivellini, A., Francini, A., \& Khan, M. I. R. (2017). Ethylene role in plant growth, development and senescence: Interaction with other phytohormones. Frontiers in Plant Science, 8, article 175, 1-19. doi: 10.3389/ fpls.2017.00475

Khan, N., Abbasi, A. M., Dastagir, G., Nazir, A., Shah, G. M., Shah, M. M., \& Shah, M. H. (2014). Ethnobotanical and antimicrobial study of some selected medicinal plants used in Khyber Pakhtunkhwa (KPK) as a potential source to cure infectious diseases BMC Complement. Alternative Medicine, 14(4), 122. doi: 10.1186/14726882-14-122 Retrieved from https:// pubmed.ncbi.nlm.nih.gov/24708514/

Kretzschmar, A. A., Marodin, G. A. B., Duarte, V., Valdebenito-Sanhueza, R. M., \& Guerra, D. S. (2007). Efeito de fitorreguladores sobre a incidência de podridão carpelar em maçãs 'Fuji'. Revista Brasileira de Fruticultura, 29(3) 414-419. doi: 10.1590/ S0100-29452007000300003 
Link, H. (2000). Significance of flower and fruit thinning on fruit quality. Plant Growth Regulation, 31, 17-26. doi: 10.10 23/A:1006334110068

Mahmood, S., Mohamaad, N. H., Ali, S. M. Y., Ripa, R. A., \& Hossain, M. G. (2016). Effect of plant plant growth regulators on fruit set and quality of guava. Turkist Journal of Agriculture - Food Science and Technology, 4(12), 1088-1091. doi: 10.24925/turjaf.v4i12.1088-1091.799

Matsunaga, M., Bemelmans, P. F., Toledo, P. E. N. de, Delley, R. D., Okawa, H., \& Pedroso, I. A. (1976). Metodologia de custo de produção utilizado pelo IEA. Agricultura em São Paulo, 23(1), 123-139. Recuperado de http://www.iea.sp.gov.br/ ftpiea/rea/tomo1_76/artigo3.pdf

Meland, M., \& Birken, E. (2010). Ethephon as a blossom and fruitlet thinner affects crop load, fruit weight and fruit quality of the European plum cultivar 'Jubileum'. Acta Horticulturae, 884, 315-321. doi: 10.176 60/ActaHortic.2010.884.36

Pavanello, A. P., \& Ayub, R. A. (2012). Aplicação de ethephon no raleio químico de ameixeira e seu efeito sobre a produtividade. Revista Brasileira de Fruticultura, 34(1), 309-316. doi: 10.1590/ S0100-29452012000100040

Ramos, D. P., Leonel, S., Silva, A. C., Souza, M. E., Souza, A. P., \& Fragoso, A. M. (2011). Pruning times in seasonality, yield and quality of 'Paluma' guava fruits. Semina: Ciências Agrárias, 32(3), 909-918. doi: 10.5433/1679-0359.2011v32n3p909

Ribeiro, L. R., Leonel, S., Souza, J. M. A., Garcia, E. L, Leonel, M., Monteiro, L. N. H.,... Ferreira, R. B. (2020). Improving the nutritional value and extending shelf life of red guava by adding calcium chloride. LWT-Food Science and Technology, 130(2020), 109655. doi: 10.1016/j.Iwt.2020.109655

Safaei-Nejad,G.,Shahsavar,A.R.,\&Mirolesmani, A. (2015). Effects of naphthalene acetic acid and carbaryl on fruit thinning in 'Kinnow' mandarin trees. Journal of Chemical Health Risks, 5(2), 137-144. doi: 10.22034/JCHR.2015.544101

Schröder, M. (2013). Correlative polar auxin transport to explain the thinning mode of action of benzyladenine on apple. Sciencia Horticulturae, 153(4), 84-92. doi: 10.1016/j.scienta.2013.02.001

Silva, M. J. R., Tecchio, M. A., Domiciano, S., Leonel, S., \& Balestero, R. (2016). Phenology, yield and fruit quality of 'Paluma' guava tree at different pruning times. Ciência e Agrotecnologia, 40(3), 317-325. doi: 10.1590/1413-705420164 03033315

Tokairin, T. de O., Capello, F. P., \& Spósito, M. B. (2014). Production cost for table guavas produced with and without bagging: case study. Revista Brasileira de Fruticultura, 36(3), 542-549. doi: 10.1590/0100-2945$347 / 13$

Torres, E., Giné-Bordonaba, J., \& Asín, L. (2021). Thinning flat peaches with ethephon and its effect on endogenous Ethylene production and fruit quality. Scientia Horticulturae, 278(27), 109872. doi: 10.10 16/j.scienta.2020.109872

Vitti, K. A., Lima, L. M., \& Martines, J. G. M., Fo. (2020). Agricultural and economic characterization of guava production in Brazil. Revista Brasileira de Fruticultura, 42(1), e447. doi: 10.1590/0100-2945202 0447 
Zwack, P. J., Robinson, B. R., Risley, M. G., \& Rashotte, A. M. (2013). Cytokinin response factor 6 negatively regulates leaf senescence and is induced in response to cytokinin and numerous abiotic stresses. Plant Cell Physiology, 54(6), 971-981. doi: 10.1093/pcp/pct049 